\title{
MONITORING OF THE UNDERMINED TERRITORIES OF KARAGANDA COAL BASIN ON THE BASIS OF SATELLITE RADAR INTERFEROMETRY
}

\author{
S.B. Ozhigina, D. V. Mozer, D.S. Ozhigin, S.G. Ozhigin, O.G. Bessimbayeva, E. N. Khmyrova, \\ Karaganda State Technological University, boulevard Mira 56, Karaganda, Kazakhstan \\ e-mail: osb66@mail.ru
}

Special Sessions, SpS 8

KEY WORDS: Monitoring, satellite radar interferometry, interferogram, geotechnical computations, leveling, basin subsidence

\begin{abstract}
:
In the Karaganda coal basin, mines are located in close proximity to each other and to the city of Karaganda and ongoing mining operations are accompanied by a dangerous process of settling the earth's surface and monitoring are essential for the region's economy. Underground mining leads to the formation of voids in the rock mass, which cause displacement of the earth surface. This paper demonstrates an innovative use of the integrated approach for monitoring on the example of Karaganda coal basin, which includes estimation of the rock mass displacement using leveling profile lines and satellite radar interferometry. It is proved that satellite radar interferometry provides reliable results of surface subsidence measurements in mining areas and can be used for considered sort of monitoring.
\end{abstract}

\section{INTRODUCTION}

The foundations of the satellite radar interferometry were developed at Italian Applied Sciences School in Milano at the beginning of 2000 under supervision of Dr. A. Ferreti (Ferretti, A., Perissin, D., Prati C., Rocca, F., 2004) and Dr. R.F.Hanssen of Delft University of Technology (Hanssen, R., 2001). Many European Universities and research organizations are working on satellite interferometry monitoring problems. Among them are Clausthal University of Technology represented by Dr.W.Bush (Hebel, H., Busch, W., Schäfer, M., Walter, D., 2008) and Dr.S.Knospe (Knospe, S., Busch, W., 2009), Braunschweig University of Technology represented by research of Dr.W.Niemeier and Dr.B.Riedel (Niemeier, W., Lehmann, M., Riedel, B., 2013), Leibniz University of Hanover - Michaelsen E., Sörgel U. (Schunert, A., Michaelsen, E., Sörgel, U., 2011), Mediterranean Technology Park in Barcelona represented by works of Drs M. Crosetto and G. Luzi and multiple efforts also performed in China (Wang, Y., Wang, J., Huang, Y., Tian, F., Chen, G., 2013). In Russian Federation Y.A. Kashnikov from Perm national research polytechnical university, Y. Kantemirov from Sovzond company, A.L. Okhotin from Irkutsk state technical university, A.V. Evtyushkin from I. Kant Baltic federal university (Kaliningrad) are engaged in satellite radar interferometry. Our research is devoted to the rock mass movement measurements.

Underground mining leads to the formation of voids in the rock mass, which cause displacement of the earth surface. Share voids to prevent collapse caused by displacement of the rock mass, for economic reasons in Kazakhstan are rarely used (Ozhigin S., Nizametdinov F., Ozhigina S., Ozhigin D., 2014).

In the Karaganda coal basin, mines are located in close proximity to each other and to the city of Karaganda and ongoing mining operations are accompanied by a dangerous process of settling the earth's surface and monitoring are essential for the region's economy (Ozhigina S., Urdubayev R., Ozhigin D., Ozhigin S., 2015).

To control these processes in the Karaganda State Technological University in collaboration with Michigan Technological
University we are working on a comprehensive approach including calculating the displacement of the earth's surface, leveling profile lines over the undermined mountain range and technology of satellite radar interferometry.

In real-time monitoring of large areas of mine workings which undermined the earth's surface, it is necessary to define a method which allows implementing it in real time with high accuracy and clarity. Described in this paper is a comparison of calculation results of displacement of the earth surface, leveling profile lines and received by satellite radar interferometry. Sedimentation showed good reproducibility in the measurement of the earth's surface subsidence underworked mine workings.

\section{DEFINITION OF UNDERMINED EARTH'S SURFACE DISPLACEMENT NEAR KUZEMBAEVA MINE BY METHOD OF GEOMETRICAL LEVELLING}

The boundaries of the danger zone were applied to mining plans T. Kuzembaev mine and presented as a circle in Figure 1. They were obtained by superimposing the mining plans of the mine on the image taken from Google maps. In the center of this area is the intersection of the railway track and the A17 freeway (Mozer D., Fofanov O., Yavorskiy V., 2014 ).

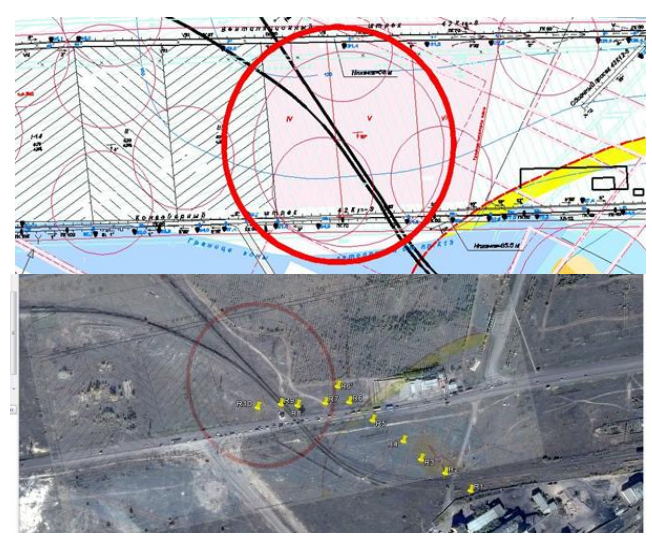

Figure 1. Determination of the undermined territory and overlapping on the territory plan in Google Maps 
For implementation of monitoring and determination of character and sizes of displacements and deformations of a terrestrial surface in the area of T. Kuzembayev mine two observational stations were installed in May, 2014. Systematic instrumental monitoring using Leica NA 730 optical level is carried out (Figure 2).

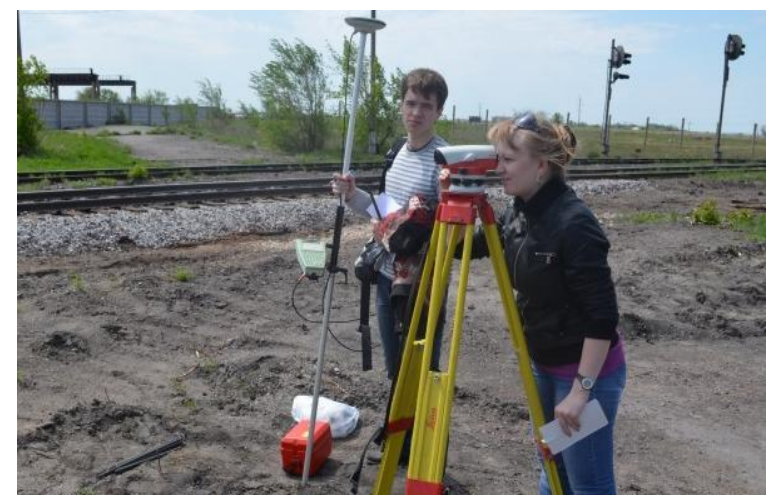

Figure 2. Carrying out of a ground monitoring

According to (Monserrat, O., Crosetto, M., Luzi, G., 2014), the time interval between the re-leveling set, based on the expected velocity of recent vertical crustal movements. Detailed information about the process of displacement, in addition to the initial and final observations, carried out at least 5 sets of observations over the interval:

$$
t=\frac{H}{6 c}=36, \text { days }
$$

where $\mathrm{H}-$ is the depth of development at the lower boundary working in meters;

$\mathrm{c}$ - speed of displacement slaughter, meters per day.

Integrated results of 5 series of leveling are shown in the graphs in Figure 3.
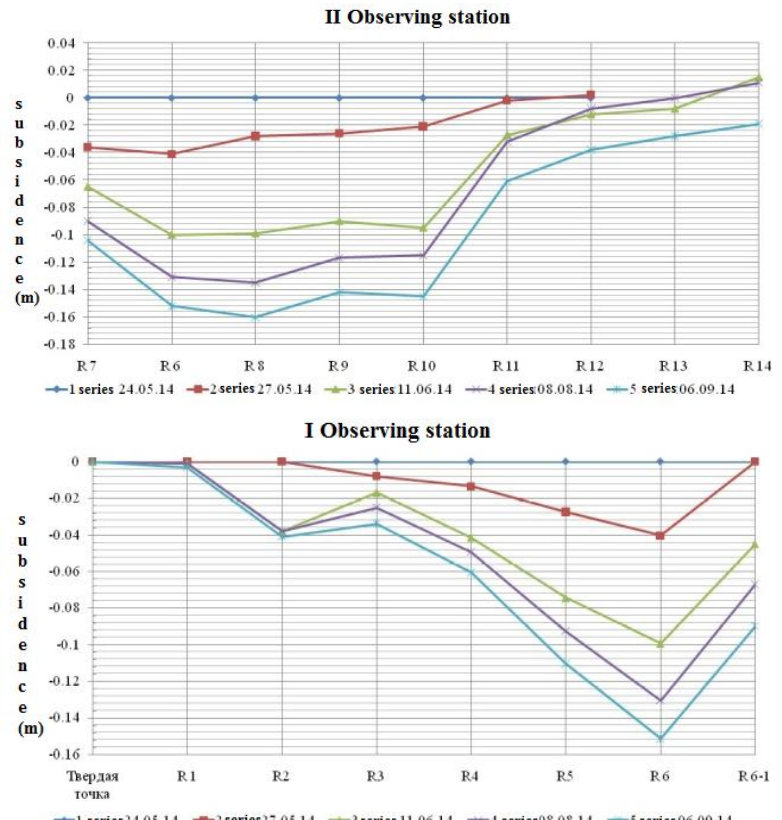

$\rightarrow 1$ series $24.05 .14-2$ series $270514+3$ series $110614-4$ series $0808.14-5$ series 06.09 .14

Figure 3. Graphical representation of the earth surface subsidence profile lines as a result of levelling
Work within the limits of the dangerous section was conducted from April to September, which is about 6 months. During this period, coal was mined in the area. Comparing our results with the results of theoretical calculations, it can be noted that the magnitude of subsidence, measured over a period of 6 months differs by $20 \%$. The maximum value of subsidence during this period amounted to $0.16 \mathrm{~m}$ (leveling) and $0.2 \mathrm{~m}$ on theoretical calculations.

\section{DEFINITION OF UNDERMINED EARTH'S SURFACE DISPLACEMENT NEAR KUZEMBAEVA MINE BY METHOD OF THE SATELLITE RADAR INTERFEROMETRY}

Currently there are 2 archival chains of radar space pictures from the ENVISAT and ALOS satellite for the territory of Karaganda city. Processed space pictures from ENVISAT satellite showed not absolutely good results. It is connected with lack of a full-fledged chain of pictures of one and the same track of the big temporary and basic line. It is possible to distinguish COSMO_SkyMed, Italy and TerraSAR-X, Germany from the existing satellite systems. Basing on the territory of interest and shooting time the Italian satellite was chosen for implementation of the project.

Figure 4 depicts some quicklooks of the satellite scenes deployed in the described research (Moser, D., Tuyakbay, A., Gey, N., Nagibin A., Satbergenova A.,2014).

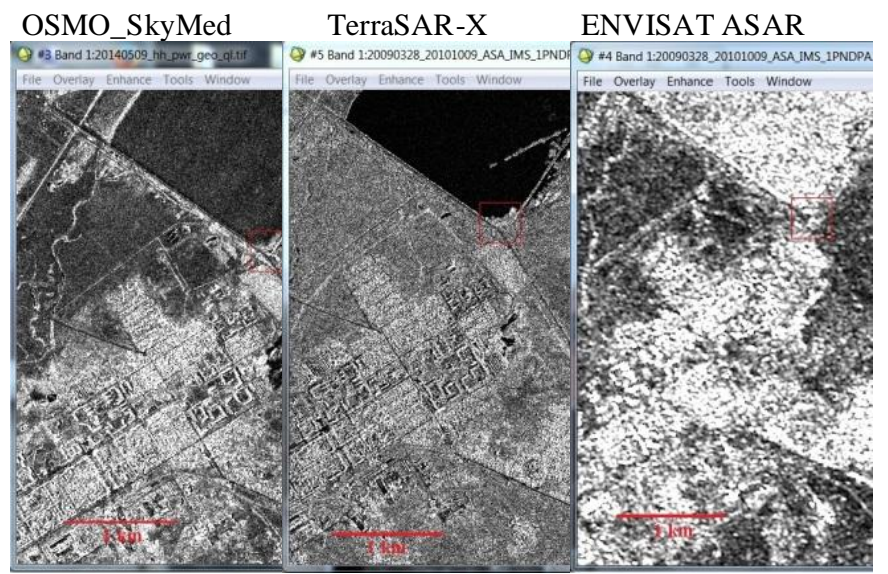

Figure 4. Selected satellite imagery quicklooks deployed for the research project

Research was based on fifteen images from satellite COSMOSkyMed (Italy) which were made in April - October, 2014 in the high-resolution mode "Stripmap". Processing of satellite images was carried out by means of ENVI SarScape module (Hebel, H.-P., Busch, W., Schäfer, M., Walter, D., 2008).

Pairs of space pictures for further processing were chosen in the "Connection Graph tool" of ENVI program in the automated mode. As a result two graphs, which display pairs of space pictures as connections in the network connecting each image with another, were created (figure 5). 

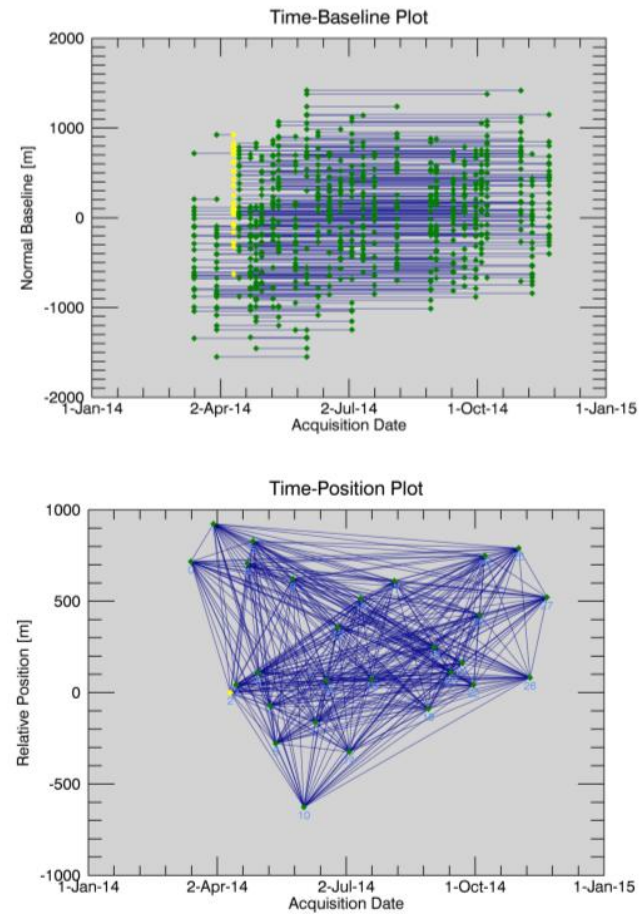

Figure 5. Definition base lines of pictures

According to the results of image processing, it was determined that the best pairs of images, with normal baseline to 1000 meters and a small time base to 10 days, and for each of them interferograms (Figure 5) were built (Mansurov, V., Satov, M., Jantuev, R., Kantemirov ,Y., 2012).

Results of processing of radar pictures showed that from April to November there was an intensive formation of subsidence area around a railway crossing and the A17 road. These subsidence troughs are located in areas of coal mining of T. Kuzembayev mine (Figure 6).
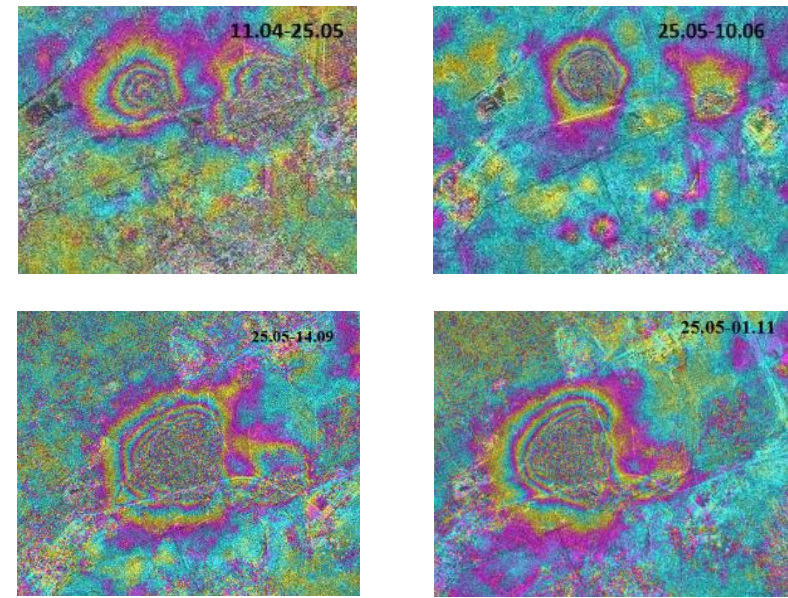

Figure 6. Samples of differential interferogram of the area of T. Kuzembaev mine based on different image pairs

As a result of space pictures processing subsidence isolines and earth surface subsidence graph for the specific point with the maximum subsidence were made. From the schedule it is notable that the maximum subsidence during supervision period made more than $145 \mathrm{~mm}$ (Figure 7).
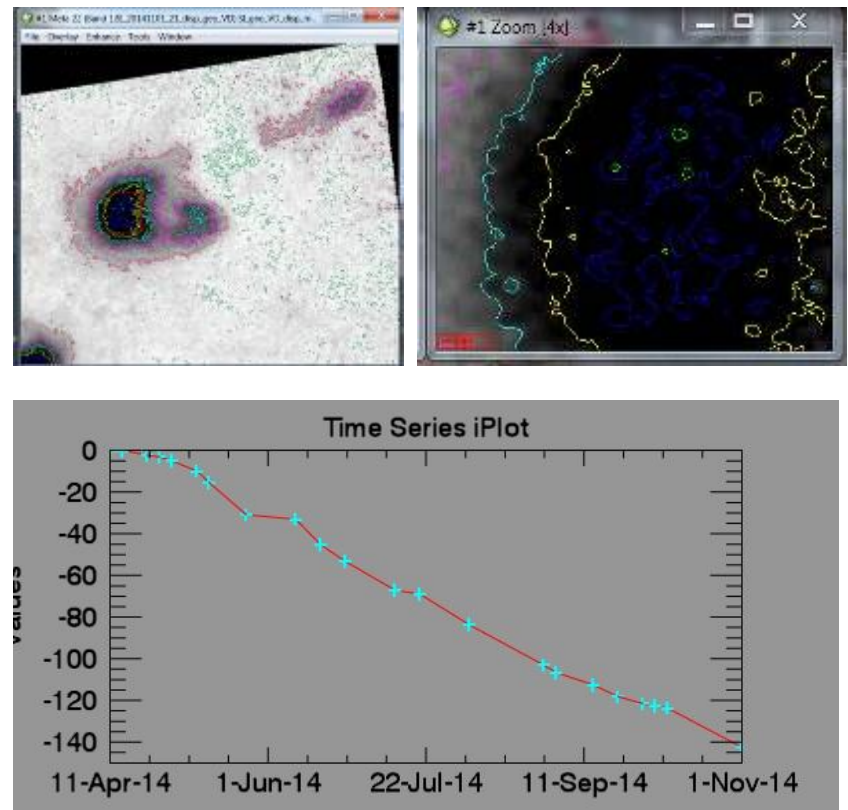

Figure 7. Isolines and subsidence graph based on 22 space pictures of the territory of T. Kuzembayev mine

From the graphs in Figure 7 it shows that the maximum subsidence during the observation period was $0.145 \mathrm{~m}$. The graph shows that at the point of maximum surface subsidence for the period from April to October, 2014 there is a good correlation between the results of ground measurements and satellite radar monitoring.

According to monitoring results , the coal department of Mittal Steel Temirtau. The recommend to add additional sections to the base construction of electric transmission lines, which are on the territory of undermined. In the spring of 2015 electric transmission lines have been reconstructed, thus avoiding breaking high-voltage wires and to prevent disturbance situations. (Figure 8)

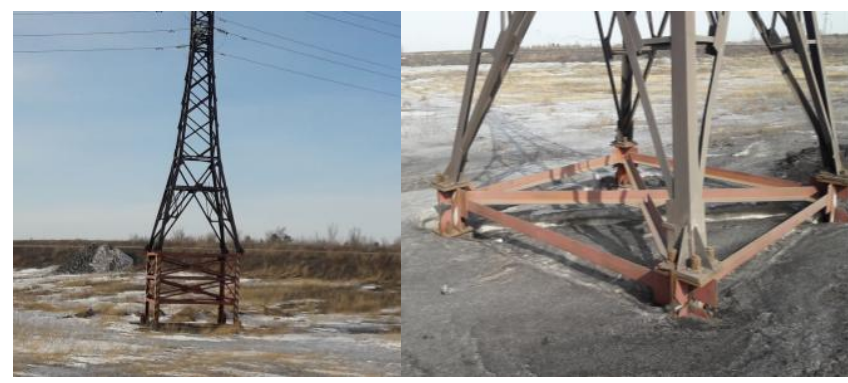

Figure 8. The reconstructed electric transmission lines, which are on the undermined territory of Kuzembaev mine.

This allows make a conclusion about the possibility of using satellite radar interferometry in practical problems of displacement monitoring the earth's surface on undermined areas.

\section{CONCLUSIONS}

Values of the ground surface subsidence, obtained by different methods showed good correlation. In this case, the satellite radar interferometry for displacement monitoring of undermined earth surface area has a number of advantages over traditional methods subsidence surveying and calculation. It should also be 
noted that it allows us to observe large territory and get visible results and timing of observations depending on the demands. This allows us to recommend satellite radar interferometry as a reliable method for monitoring of subsidence and deformations of the rock mass.

\section{ACKNOWLEDGEMENTS}

Authors would like to express their gratitude to German Academic Exchange Service DAAD for the grant supporting of this research under the leadership of professor V. Bush at technical university of Clausthal.

We would also like to extend our appreciation to the Scientific Committee of the Ministry of Education and Science of the Republic of Kazakhstan for the allocating grant \# 1596 of September 21, 2012. Our sincere appreciation is extended to the colleagues in the Department of Mine Surveying and Geodesy for ongoing technical assistance and discussion in the course of this work and to the center of Commercialization of technologies of the Ministry of Education and Science of the Republic of Kazakhstan within which the conducted research is implemented.

\section{REFERENCES CITED}

Ferretti, A., Perissin, D., Prati C., Rocca, F., 2004. ERSENVISAT Permanent Scatterers, Geoscience and Remote Sensing Symposium, 2004. IGARSS '04. Proceedings. 2004 IEEE International (Volume:2), pp. 985 - 988.

Hanssen, R. F., 2001. Radar Interferometry: Data Interpretation and Error Analysis, Kluwer Academic Publish., Dordrecht, $328 \mathrm{p}$.

Hebel, H.-P., Busch, W., Schäfer, M., Walter, D., 2008. Subsidence monitoring over a collapsed mine in Berezniki, Russia. Proceedings of the 3rd TerraSAR-X Science Team Meeting, 2526 November 2008, DLR, Oberpfaffenhofen, Germany.

Knospe, S., Busch, W., 2009. Monitoring a tunneling in an urbanized area with Terrasar-X interferometry - Surface deformation measurements and atmospheric error treatment. Geoscience and Remote Sensing Symposium,2009 IEEE International, IGARSS 2009(Volume:2), pp. II-25 - II-28.

Mansurov, V., Satov, M., Jantuev, R., Kantemirov ,Y., 2012. Space Radar Monitoring of Earth surface and structures on the Zhezkazgan copper deposit, Journal of geoinformatics and remote sensing of the earth, 2012(1):77-83.

Monserrat, O., Crosetto, M., Luzi, G., 2014. A review of ground-based SAR interferometry for deformation measurement, ISPRS Journal of Photogrammetry and Remote Sensing, 93:40-48.

Moser, D., Tuyakbay, A., Gey, N., Nagibin A., Satbergenova A.,2014. Monitoring of the undermined Karaganda coal basin using satellite radar interferometry, Procs. of Intergeo-Siberia, Novosibirsk, Russia, April 2014.

Niemeier, W., Lehmann, M., Riedel, B., 2013. Qualitätssicherung bei der terrestrischen Radar-interferometrie. In Schriftenreihe des DVW: Qualitätssicherung geodätischer Mess- und Auswerteverfahren, Augsburg, Band 71.
Schunert, A., Michaelsen, E., Sörgel, U., 2011. Perceptual grouping for persistent scatterers in urban high-resolution SAR images. In: Proceedings of IEEE International Geoscience and Remote Sensing Symposium (IGARSS), Vancouver, 2011, pp. 2708-2711.

Wang Yunjia, Wang Jian, Huang Yi, Tian Feng, Chen Guoliang., 2013. Technologies and applications for multi-source monitoring of surface disasters in mining area, International Society for Mine Surveying XV International ISM Congress 2013, Deutscher Markscheider-Verein e.V. - DMV, 16-20 September, Aachen, Germany, pp. 1034-1048.

Ozhigina S., Urdubayev R., Ozhigin D., Ozhigin S. Monitoring stability boards of deep open pit jsc «SSGPO». Interexpo GeoSiberia-2015. XIth International scientific congress: International Scientific Conference "Geodesy, geoinformatics, cartography , mine survey». Novosibirsk, SSUGT, 2015. Volume 1, part 2, pp. 210-215.

Ozhigin S., Nizametdinov F., Ozhigina S., Ozhigin D. Innovative methods of monitoring of the condition of stability of rocks andterrestrial surface. Interexpo Geo-Siberia-2014. Xth International scientific congress: International Scientific Conference "Geodesy, geoinformatics, cartography, mine survey». Novosibirsk, SSAG, 2014. Volume 1, part 1, pp. 135140.

Mozer D., Fofanov O., Yavorskiy V., 2014. Space Monitoring of Man-Made Hazards in Central Kazakhstan, Mechanical Engineering, Automation and Control Systems (MEACS), 2014 International Conference. ISBN: 978-1-4799-6220-4 Tomsk pp $1-4$. 